\title{
The non-haem chloroperoxidase from Pseudomonas fluorescens and its relationship to pyrrolnitrin biosynthesis
}

\author{
Sabine Kirner, ${ }^{1}$ Susanne Krauss, ${ }^{1}$ Gisela Sury, ${ }^{1}$ Stephen T. Lam, ${ }^{2}$ \\ Jim M. Ligon ${ }^{2}$ and Karl-Heinz van Pée ${ }^{3}$
}

Author for correspondence: Karl-Heinz van Pée. Tel: +49351 463 4494. Fax: +49351 4635506.
e-mail: chr@ctch02.chm.tu-dresden.de

1 Institut für Mikrobiologie, Universität Hohenheim, Garbenstrasse 30, D-70593

Stuttgart, Germany

2 Department of Molecular Genetics, CIBA Agricultural Biotechnology, Research Triangle Park, North

Carolina, USA

3 Institut für Biochemie, Technische Universitat Dresden, D-01062 Dresden, Germany

\begin{abstract}
The non-haem chloroperoxidase gene (cpof) from the pyrrolnitrin producer Pseudomonas fluorescens BL914 was cloned using an oligonucleotide derived from part of the $\mathrm{N}$-terminal amino acid sequence of chloroperoxidase (CPO-P) from Pseudomonas pyrrocina as a probe. Based on the overexpression of cpoF in Escherichia coli and the stabilty of CPO-F against higher temperatures and proteases, the enzyme was purified to homogeneity. Partial characterization of the enzyme showed that it belongs to the class of bacterial non-haem CPOs. To investigate the role of CPO-F in pyrrolnitrin biosynthesis, the cpoF gene was inactivated by insertion of a kanamycin cassette. Exchange of the chromosomal cpof gene against the disrupted copy had no influence on pyrrolnitrin production demonstrating that CPO-F was not involved in pyrrolnitrin biosynthesis.
\end{abstract}

Keywords: Pseudomonas fuorescens, pyrrolnitrin, chloroperoxidase, gene disruption

\section{INTRODUCTION}

Haloperoxidases are a widely distributed family of enzymes catalysing the formation of carbon-halogen bonds in the presence of hydrogen peroxide, halide ions and a suitable organic substrate. According to molecular and catalytic properties, they can be divided into two classes: haem-type and non-haem-type haloperoxidases. The haem enzymes, such as chloroperoxidase (CPO) from Caldariomyces fumago (Hager et al., 1966), usually contain protoporphyrin IX as prosthetic group and exhibit catalase and peroxidase activities (Neidleman \& Geigert, 1986). The non-haem enzymes can be subdivided into two groups: eukaryotic haloperoxidases which contain vanadium (Vilter, 1984; Wever et al., 1985) and bacterial non-haem haloperoxidases which require neither metal ions nor any other cofactors (Hecht et al., 1994). According to the halide ions that they can oxidize, haloperoxidases are designated as chloroperoxidases, bromoperoxidases and iodoperoxidases.

Naturally occurring halogenated compounds have been isolated from many different organisms including pro-

Abbreviations: $\mathrm{CPO}$, chloroperoxidase; $c p o$, gene encoding chloroperoxidase; DIG, digoxigenin karyotes, fungi, plants and mammals. It has been widely accepted that haloperoxidases are involved in the formation of organohalogens (Neidleman \& Geigert, 1986; van Pée, 1990). Among the most interesting and best studied organohalogens are the chlorinated antibiotics like chloramphenicol (Ehrlich et al., 1947), 7 chlorotetracycline (Duggar et al., 1948), vancomycin (McCormick et al., 1956) and pyrrolnitrin (Arima et al., 1964) that are produced by bacteria.

Pyrrolnitrin, a chlorine-containing phenyl-pyrrole derivative with antifungal activity, was isolated from a number of Pseudomonas strains (Arima et al., 1964; Elander et al., 1968; Imanaka et al., 1965). On the basis of metabolites isolated, a hypothetical pathway for pyrrolnitrin biosynthesis (Fig. 1) was postulated (van Pée et al., 1980). From the pyrrolnitrin producer Pseudomonas pyrrocinia, a CPO (CPO-P) was isolated that catalysed the chlorination of monodechloroaminopyrrolnitrin to aminopyrrolnitrin in vitro (Wiesner et al., 1988) and the last step of pyrrolnitrin biosynthesis, the oxidation of the amino group of aminopyrrolnitrin to the nitro group of pyrrolnitrin (Kirner \& van Pée, 1994). This strongly suggested the participation of this $\mathrm{CPO}$ in pyrrolnitrin biosynthesis.

To further investigate the role of non-haem CPOs in 


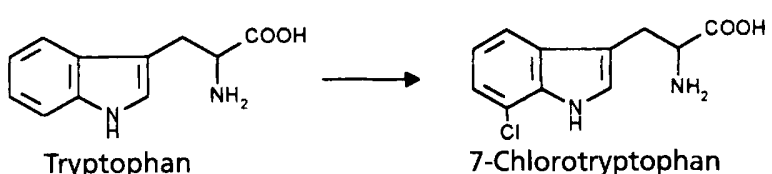

Tryptophan<smiles>Nc1c(Cl)cccc1-c1ccc[nH]1</smiles>

Monodechloroaminopyrrolnitrin

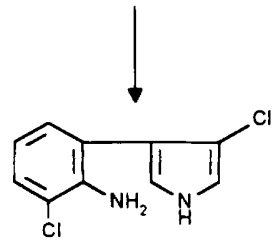

Aminopyrrolnitrin

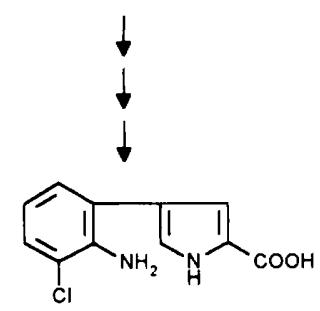

Monodechloroaminopyrrolnitrincarboxylic acid

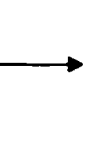<smiles>O=[N+]([O-])c1c(Cl)cccc1-c1c[nH]cc1Cl</smiles>

Pyrrolnitrin

Fig. 1. Hypothetical biosynthetic pathway of pyrrolnitrin biosynthesis according to van Pée et al. (1980). All of the shown intermediates with the exception of 7-chlorotryptophan have been isolated.

pyrrolnitrin biosynthesis, a genetic approach was adopted. Here we describe the cloning of a CPO gene $(c p o F)$ from Pseudomonas fluorescens BL914, the purification of the corresponding enzyme, its partial characterization, a gene replacement experiment and its effect on pyrrolnitrin biosynthesis.

\section{METHODS}

Bacteria, plasmids and culture conditions. P. fluorescens BL914 (Hill et al., 1994), with or without plasmid pCIB137, containing a global regulatory gene for antifungal activity (Gaffney et al., 1994) was grown at $30^{\circ} \mathrm{C}$, either on $\mathrm{LB}$ medium or on Pseudomonas minimal medium (PMM), consisting of $35 \mathrm{mM}$ $\mathrm{K}_{2} \mathrm{HPO}_{4} \cdot 3 \mathrm{H}_{2} \mathrm{O}, 22 \mathrm{mM} \mathrm{KH} \mathrm{PO}_{4}, 8 \mathrm{mM}\left(\mathrm{NH}_{4}\right)_{2} \mathrm{SO}_{4}, 25 \mathrm{mM}$ sodium succinate and $1.2 \mathrm{mM} \mathrm{MgSO}$. Escherichia coli TG1 (Gibson, 1984) and E. coli S17-1 (Simon et al., 1983) were routinely grown either in liquid LB medium or on LB agar plates at $37^{\circ} \mathrm{C}$. When required for the maintenance of plasmids, antibiotics were added at the following concentrations: ampicillin, $100 \mu \mathrm{g} \mathrm{ml}^{-1}$; tetracycline, $20 \mu \mathrm{g} \mathrm{m}^{-1}$; kanamycin, $50-$ $100 \mu \mathrm{g} \mathrm{m} \mathrm{m}^{-1}$. For routine cloning and subcloning in E. coli, pUC18 and pUC19 (Vieira \& Messing, 1982) and pBR322 (Bolivar et al., 1977) were used. E. coli transformants carrying pUC18 or pUC19 were selected on LB agar containing ampicillin $\left(100 \mu \mathrm{g} \mathrm{ml}^{-1}\right), X-G a l\left(40 \mu \mathrm{g} \mathrm{ml}^{-1}\right)$ and $0 \cdot 2 \mathrm{mM}$ IPTG. For isolation of the kanamycin cassette, pUC4K obtained from Pharmacia was used.

Bacterial conjugation. Plasmid DNA was introduced from $E$. coli into $P$. fluorescens by a biparental procedure utilizing the donor host E. coli S17-1 with tra genes integrated into the donor strain chromosome (Simon et al., 1983). Selection for

exconjugants was performed on PMM agar containing kanamycin and tetracycline allowing only recombinant Pseudomonas cells to grow.

DNA isolation and manipulations. Total DNA was prepared as described by Davis et al. (1980). Plasmid DNA was isolated by the alkaline lysis method (Sambrook et al., 1989). Agarose gel electrophoresis, restriction endonuclease digestions, treatmient with alkaline phosphatase and DNA ligations were performed according to standard procedures (Sambrook et al., 1989). DNA fragments were isolated from agarose gels with the Geneclean II kit (Dianova) as recommended by the supplier. Oligonucleotides and DNA probes for use in Southern hybridization (Southern, 1975) were labelled with digoxigenin (DIG) as recommended by the manufacturer (Boehringer Mannheim) with the DIG Oligonucleotide 3'-End Labelling Kit and the DIG DNA Labelling Kit, respectively.

Transfers and hybridizations. DNA fragments separated by agarose gel electrophoresis were denatured $(0.5 \mathrm{M} \mathrm{NaOH}$, $1.5 \mathrm{M} \mathrm{NaCl})$, equilibrated $(0.25 \mathrm{M} \mathrm{NaOH}, 1.5 \mathrm{M} \mathrm{NaCl})$ and transferred (Sambrook et al., 1989) to a nylon membrane (Schleicher \& Schuell). Colony screening (Sambrook et al., 1989) was performed on Hybond-N gridded membranes (Amersham-Buchler) according to the manufacturer's instructions. Detection of hybridizing DNA fragments and colonies was perfomed with the DIG Luminescent Detection Kit (Boehringer Mannheim).

Hybridization experiments using a mixed 17-mer oligonucleotide [TTT(C)TAT(C)AAA $(G) G A T(C) T G G ~ G G]$ that corresponded to the amino acid residues $12-17$ of the $\mathrm{N}$ terminus of CPO-P from P. pyrrocinia (Wolfframm et al., 1988) as the probe, were carried out overnight at $43^{\circ} \mathrm{C}$ in $2 \times \operatorname{SSC}(1 \times$ SSC: $0.15 \mathrm{M} \mathrm{NaCl}, 0.015 \mathrm{M}$ sodium citrate, $\mathrm{pH} 7.0$ ). The membranes were stringently washed twice in $2 \times \mathrm{SSC}$ containing $0.1 \%$ SDS at $43^{\circ} \mathrm{C}$ for $15 \mathrm{~min}$ and then twice in $1 \times \mathrm{SSC}$ containing $0.1 \%$ SDS at $43^{\circ} \mathrm{C}$ for $15 \mathrm{~min}$.

Using the DIG-labelled $1.2 \mathrm{~kb} \mathrm{KpnI} \mathrm{fragment} \mathrm{as} \mathrm{a} \mathrm{probe} \mathrm{for}$ identification of the original, functional $c p o F$ gene and the disrupted $c p o F$ copy, hybridizations and washing steps were carried out at $80^{\circ} \mathrm{C}$, as described above. The last stringent wash was performed twice for $15 \mathrm{~min}$ in $0 \cdot 1 \times \mathrm{SSC}, 0 \cdot 1 \%$ SDS.

Subcloning and construction of the replacement vector. For subcloning in $E$. coli, fragments were isolated from agarose gels and ligated with linearized pUC18. For inactivation of the $c p o F$ gene, pUC4K was digested with $\mathrm{Bam} \mathrm{HI}$ and the $1.3 \mathrm{~kb}$ fragment containing the kanamycin cassette was ligated into a $0.3 \mathrm{~kb}$ deletion in the $c p o F$ gene, obtained by digestion of pSK380 with $B g / \mathrm{II}$, resulting in pSK480. After digestion of pSK480 with EcoRI and partial digestion with HindIII, the generated fragments were separated by agarose gel electrophoresis. The appropriate $4.8 \mathrm{~kb}$ EcoRI-HindIII fragment was isolated and ligated to EcoRI-HindIII-digested pBR322 resulting in pSK48D.

Enzyme assays, protein electrophoresis and protein measurements. Brominating activity was measured using the monochlorodimedone assay (Hager et al., 1966) with $42 \mu \mathrm{M}$ monochlorodimedone, $8.8 \mathrm{mM} \mathrm{H} \mathrm{H}_{2} \mathrm{O}_{2}, 0.1 \mathrm{M} \mathrm{NaBr}, 10 \mathrm{mM}$ sodium azide in $1 \mathrm{M}$ sodium acetate buffer, $\mathrm{pH} 5.5$, at $25^{\circ} \mathrm{C}$, recording the decrease of monochlorodimedone absorbance at $290 \mathrm{~nm}$ due to the formation of monobromomonochlorodimedone. One unit of CPO catalysed the bromination of $1 \mu \mathrm{mol}$ monochlorodimedone to monobromomonochlorodimedone in $1 \mathrm{~min}$. Sodium azide was necessary for the inhibition of haem-containing catalases and peroxidases. 
Non-haem chloroperoxidase and pyrrolnitrin biosynthesis

For electrophoresis of native enzymes, 7.5\% (w/v) polyacrylamide gels ( $\mathrm{pH} 7.5$ ) were used (Maurer, 1964). Brominating activity was detected after native electrophoresis by the conversion of phenol red to bromophenol blue as described by Pfeifer et al. (1992). SDS-PAGE was performed according to Schägger \& von Jagow (1987) using 4\% stacking gels and 10\% resolving gels. For estimation of subunit sizes, low molecular mass standards (Pharmacia) were used. Gels were stained for proteins with Coomassie Blue R250.

Protein concentrations were determined using the method of Whitaker \& Granum (1980).

Purification of CPO-F from E. coli TG1 containing PSK230. For purification of CPO-F, E. coli TG1 containing $c p o F$ on a $2.3 \mathrm{~kb}$ $X$ hol fragment in pUC18 (pSK230) was used. E. coli cells were grown in $6 \times 1 \mathrm{l} \mathrm{LB}$ medium for $24 \mathrm{~h}$ in the presence of ampicillin and IPTG, harvested by centifugation, resuspended

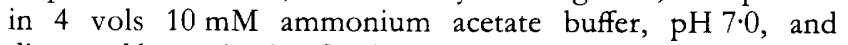
disrupted by sonication for $6 \mathrm{~min}$ (Branson Sonifier 450, $160 \mathrm{~W}$, $50 \%$ duty cycle, $4{ }^{\circ} \mathrm{C}$ ). The crude extract obtained by centrifugation $\left(22100 \mathrm{~g}, 4^{\circ} \mathrm{C}, 30 \mathrm{~min}\right)$ of the sonicate was stored at $-20^{\circ} \mathrm{C}$ or used immediately for further purification.

Ammonium sulphate was added to the crude extract to $35 \%$ saturation at $0{ }^{\circ} \mathrm{C}$. After centrifugation $\left(22100 \mathrm{~g}, 4{ }^{\circ} \mathrm{C}, 20 \mathrm{~min}\right)$, ammonium sulphate was added to the supernatant to $50 \%$ saturation. The pellet obtained by centrifugation was dissolved in the original volume of $10 \mathrm{mM}$ ammonium acetate buffer, $\mathrm{pH}$ $7 \cdot 0$, and dialysed twice against this buffer for $2 \mathrm{~h}$ each time. The protein solution was slowly heated to $55^{\circ} \mathrm{C}$ on a water bath with continuous stirring and then centrifuged immediately $(22100 \mathrm{~g}$, $4{ }^{\circ} \mathrm{C}, 20 \mathrm{~min}$ ). The supernatant of the heat treatment was diluted with buffer to a protein concentration of $5 \mathrm{mg} \mathrm{ml}^{-1}$ and 0.01 vols trypsin solution $\left(10 \mathrm{mg} \mathrm{ml}^{-1}\right.$ in $\left.1 \mathrm{mM} \mathrm{HCl}\right)$ was added. After incubation at $37^{\circ} \mathrm{C}$ for $16 \mathrm{~h}$, the solution was concentrated and washed with $10 \mathrm{mM}$ sodium acetate buffer, $\mathrm{pH} 5 \cdot 5$, by ultrafiltration (Amicon YM30 membrane). The resulting protein solution, concentrated to about one-fifth of its original volume, was loaded onto a DEAE-Sephacel column $(1.5 \times 6 \mathrm{~cm})$, equilibrated with $10 \mathrm{mM}$ sodium acetate buffer, $\mathrm{pH} 5.5$. After washing the column with this buffer, proteins were eluted using a gradient $(100 \mathrm{ml})$ of $0-0.6 \mathrm{M} \mathrm{NaCl}$ in buffer. Fractions $(1.5 \mathrm{ml})$ with at least $20 \%$ of the brominating activity of the most active fraction were pooled and concentrated to about one-tenth of its original volume by ultrafiltration.

The concentrated solution was loaded onto a Sephacryl S 300 column $(2.5 \times 160 \mathrm{~cm})$, equilibrated with $0.1 \mathrm{M}$ ammonium acetate buffer, $\mathrm{pH} 6 \cdot 8$. Fractions $(2 \mathrm{ml})$ with at least $10 \%$ of the brominating activity of the most active fraction were pooled, concentrated by ultrafiltration and stored at $-20^{\circ} \mathrm{C}$.

Chlorination of indole to 3-chloroindole by CPO-F. Chlorination of indole was performed as described by Bantleon $e t$ al. (1994) with $0.1 \mathrm{mM}$ indole, $100 \mathrm{mM} \mathrm{NaCl}, 29 \mathrm{mM} \mathrm{H}_{2} \mathrm{O}_{2}$ in a total volume of $10 \mathrm{ml}$ of $1 \mathrm{M}$ sodium acetate buffer, $\mathrm{pH} 4 \cdot 5$. The reaction was started by addition of $1 \mathrm{U}$ of brominating activity of CPO-F and incubated at room temperature. The reaction was analysed by HPLC at $280 \mathrm{~nm}$ using a $\mathrm{C}_{18}$ reverse phase column $(125 \times 4.6 \mathrm{~mm})$ with methanol/water $(60: 40, \mathrm{v} / \mathrm{v})$ as the eluent. Under these conditions 3-chloroindole was eluted at $9 \cdot 5 \mathrm{~min}$.

Measurement of pyrrolnitrin production. Cultures were incubated in LB medium for $48 \mathrm{~h}$ and extracted with 0.7 vols ethyl acetate. The extract, after evaporation, was taken up in a small volume of ethanol and analysed by thin-layer chromatography on silica gel with toluene as the eluent. Pyrrolnitrin was detected by spraying with van Urk's reagent (Stahl \& Kaldewey, 1961).
The samples were additionally analysed by HPLC at $252 \mathrm{~nm}$ using a $\mathrm{C}_{18}$ reverse phase column $(125 \times 4.6 \mathrm{~mm})$ with methanol/water $(70: 30)$.

\section{RESULTS}

\section{Cloning, subcloning and partial restriction mapping of cpoF from P. fluorescens BL914}

The oligonucleotide derived from the $\mathrm{N}$-terminal amino acid sequence of CPO-P from $P$. pyrrocinia hybridized with a $9 \mathrm{~kb}$ EcoRI fragment of total DNA from $P$. fuorescens BL914 (Fig. 2). The enriched gene library was prepared by separating EcoRI-digested total DNA on an agarose gel and ligating the isolated DNA in the range of $9 \mathrm{~kb}$ into pUC18. Transformation of $E$. coli with the ligation mixture yielded about 400 transformants. Colony hybridization led to the identification of a single recombinant clone harbouring plasmid pSK900. Crude extracts of this clone showed brominating activity in the same range as $P$. fluorescens BL914.

For restriction mapping, pSK 900 was digested with different restriction enzymes and the fragments were separated by agarose gel electrophoresis. Southern blotting and hybridization studies with the oligonucleotide probe led to the partial restriction map shown in Fig. 3. By ligating a $3.8 \mathrm{~kb}$ EcoRI-Bam HI fragment into pUC18, a subclone (pSK380) was obtained that showed moderate overexpression of brominating activity and was suitable for the gene replacement experiment. Further subcloning using XboI resulted in pSK230 containing cpoF on a $2.3 \mathrm{~kb}$ insert. E. coli clones harbouring pSK230 overexpressed brominating activity about 50 times, compared to $P$. fluorescens BL914 and E. coli clones harbouring pSK900, and were used for enzyme purification. The smallest insert conferring brominating activity was a $1 \cdot 2 \mathrm{~kb} \mathrm{KpnI} \mathrm{fragment} \mathrm{(Fig.} \mathrm{3).}$

\section{Disruption of $\mathrm{CpoF}$}

For construction of the gene replacement vector, the $3.8 \mathrm{~kb}$ insert of pSK380 was used. Digestion of pSK380 with $B g / I \mathrm{I}$ resulted in a $300 \mathrm{~kb}$ deletion (Figs 3 and 4). As a selectable marker, the $1.3 \mathrm{~kb}$ kanamycin cassette from pUC4K was inserted at the site of the deletion, yielding pSK480. E. coli clones harbouring pSK480 did not produce CPO-F or any other haloperoxidase (Fig. 5). For introduction of the disrupted $c p o F$ gene into $P$. fluorescens by conjugation, the insert of pSK 480 was religated into pBR322 resulting in the donor plasmid pSK48D that was transferred from E. coli S17-1 into P. fluorescens BL914 by biparental mating. As pSK48D cannot replicate in Pseudomonas, only such $P$. fuorescens clones could survive on PMM medium containing kanamycin that had the marker gene integrated into the chromosome. Single crossover mutants could be distinguished from double crossover mutants by sreening the kanamycin-resistant clones for loss of tetracycline resistance. Approximately $90 \%$ of the kanamycin-resistant exconjugants were tetracycline-sensitive. Analysis of the total DNA of these 
(a)

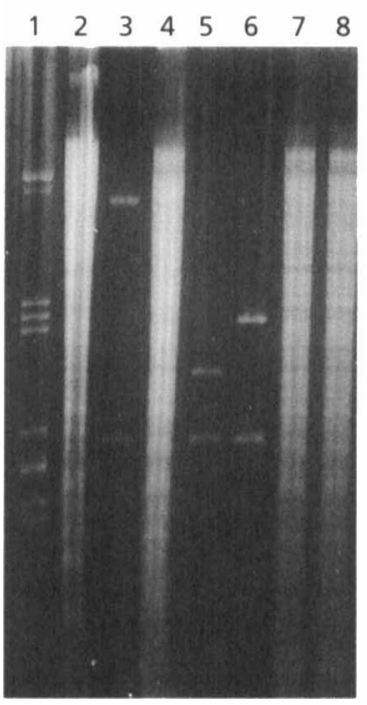

(b)

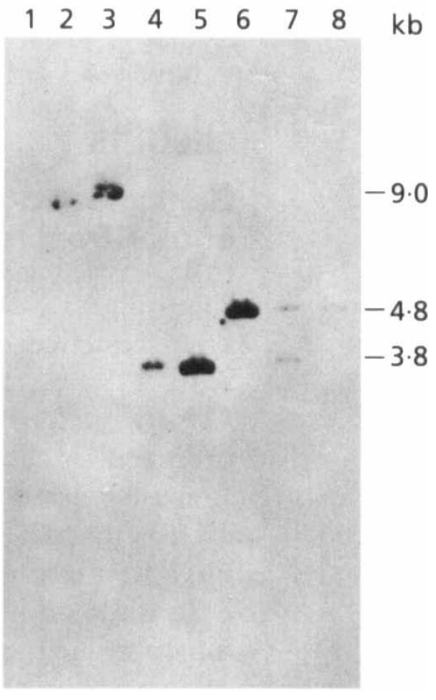

Fig. 2. (a) Agarose gel electrophoresis and (b) Southern hybridization of total DNA from P. fluorescens BL914, plasmid DNA and total DNA from single and double crossover mutants of $P$. fluorescens BL914 using the $1.2 \mathrm{~kb}$ insert of pSK120 as a probe. Lanes: 1, Pstl-digested $\lambda$-DNA; 2, EcoRl-digested total DNA from $P$. fluorescens BL914; 3, EcoRI-digested pSK900; 4, EcoRI-BamHIdigested total DNA from $P$. fluorescens BL914; 5, EcoRI-BamHI-digested pSK380; 6, EcoRI-BamHI-digested pSK480; 7, EcoRIBamHI-digested total DNA from a single crossover mutant of $P$. fluorescens BL914; 8 , EcoRI-BamHI-digested total DNA from a double crossover mutant of $P$. fluorescens BL914.

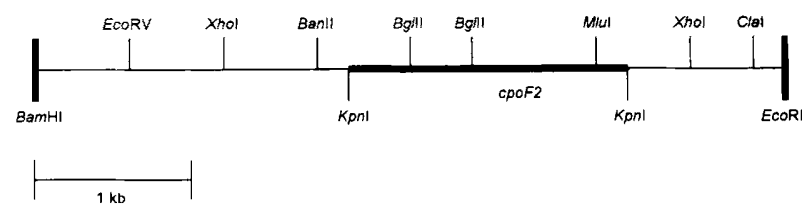

Fig. 3. Partial restriction map of the $3 \cdot 8 \mathrm{~kb}$ BamHI-EcoRI insert of pSK380. The smallest subclone exhibiting brominating activity is marked with a bold line.

clones by Southern hybridization showed that they only contained a copy of the $c p o F$ gene, inactivated by the incorporation of the kanamycin cassette (Fig. 2).

In P. fuorescens BL914 pyrrolnitrin production is regulated by a global regulatory gene for antifungal activity which had been cloned into pCIB137 (Gaffney et al., 1994). Therefore, pCIB137 was introduced into the double crossover mutants of P. fluorescens BL914 by conjugation. Analysis of clones containing only an inactivated copy of the $c p o F$ gene and pCIB137 for pyrrolnitrin production showed that they still produced pyrrolnitrin at the same level as P. furorescens BL914(pCIB137) containing an active copy of the $c p o F$ gene.

\section{Purification of CPO-F from E. coli TG1 harbouring pSK230}

CPO-F was overexpressed by E. coli clones harbouring pSK230. These clones produced about 50 times more of the enzyme than P. fluorescens BL914. The enzyme was purified by fractionated ammonium sulphate precipitation between $35-50 \%$ ammonium sulphate saturation, followed by heat treatment at $55^{\circ} \mathrm{C}$, digestion of contaminating proteins with trypsin, removal of digested, smaller proteins and peptides by ultrafiltration, ion

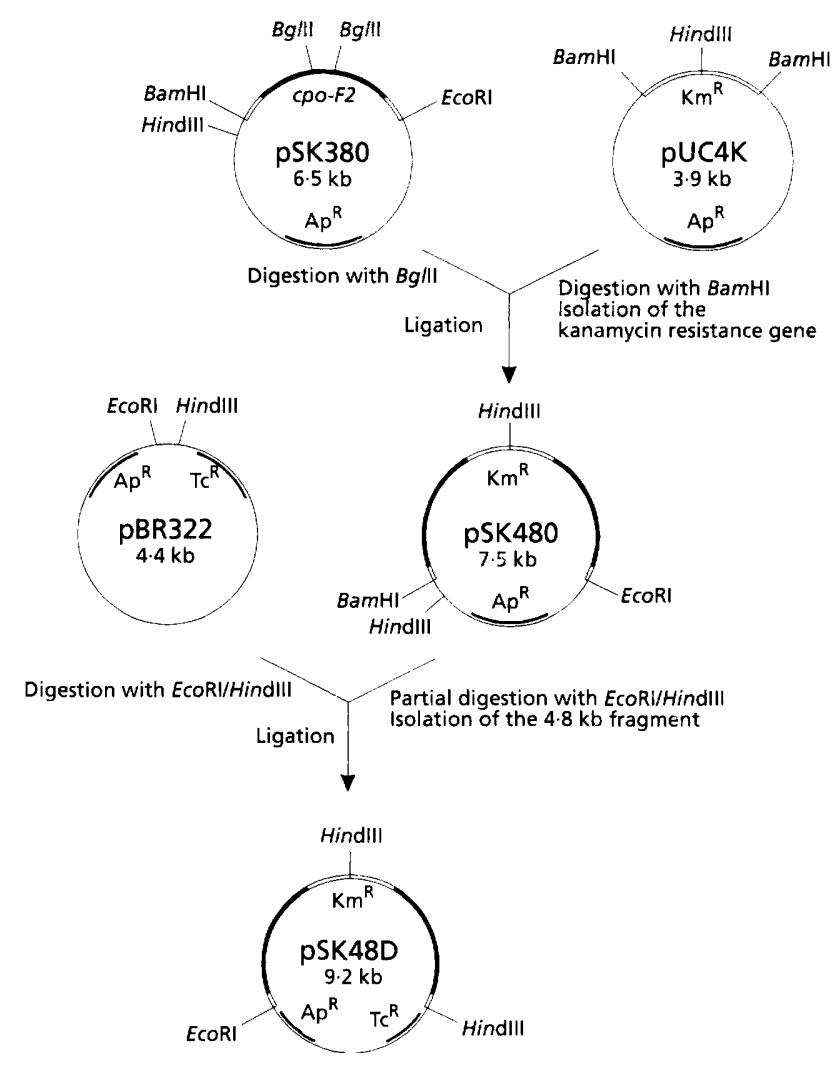

Fig. 4. Construction of the gene replacement vector pSK48D The approximate location of $c p o F$ is indicated by bold lines.

exchange chromatography on DEAE Sephacel and molecular sieve chromatography on Sephacryl S 300. From $6 \mathrm{~g}$ of cells, $22 \mathrm{mg}$ of electrophoretically homogeneous CPO (Fig. 5) with a specific activity of $3.8 \mathrm{U}$ 
(a)

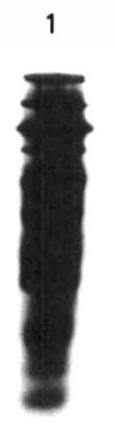

2

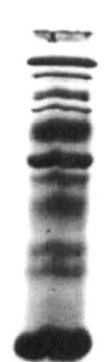

3

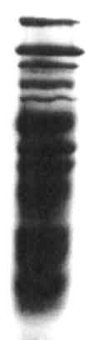

(b)

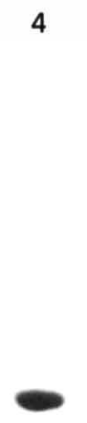

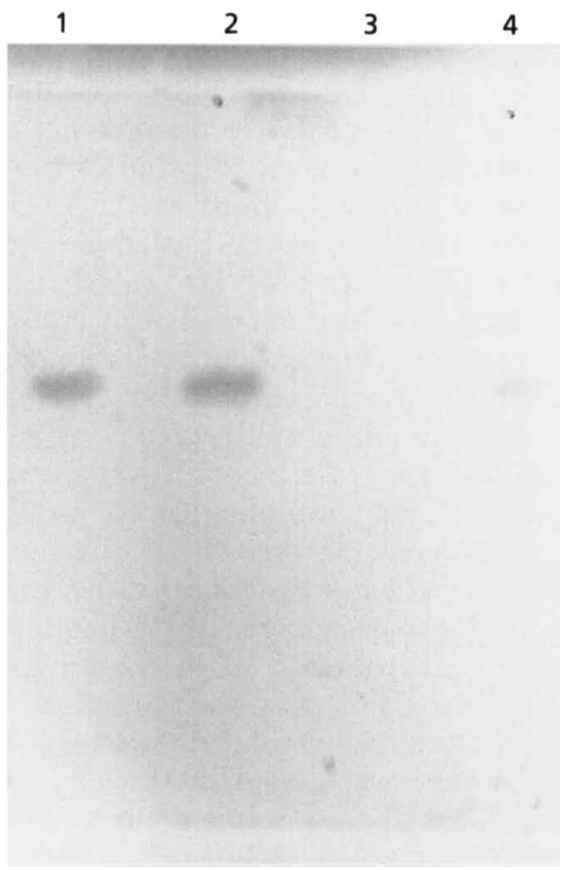

Fig. 5. Native PAGE of crude extracts and purified CPO-F (a) stained for protein and (b) stained for brominating activity. Lanes: 1 , crude extract of $P$. fluorescens BL914 harbouring PCIB137; 2 , crude extract of $E$. coli harbouring pSK380; 3 , crude extract of $E$. coli harbouring pSK480; 4, CPO-F from P. fluorescens BL914 purified from $E$. coli harbouring pSK230.

Table 1. Purification of CPO-F from E. coli harbouring PSK 230

\begin{tabular}{|c|c|c|c|c|}
\hline Step & $\begin{array}{c}\text { Total protein } \\
(\mathrm{mg})\end{array}$ & $\begin{array}{c}\text { Total activity } \\
\text { (U) }\end{array}$ & $\begin{array}{c}\text { Specific activity } \\
{\left[\mathrm{U}(\mathrm{mg} \text { protein })^{-1}\right]}\end{array}$ & $\begin{array}{c}\text { Yield } \\
(\%)\end{array}$ \\
\hline Crude extract & 1680 & 176 & $0 \cdot 1$ & 100 \\
\hline Ammonium sulphate precipitation & 263 & 168 & $0 \cdot 6$ & 95 \\
\hline Heat treatment & 166 & 130 & $0 \cdot 8$ & 74 \\
\hline Trypsin digestion & 108 & 120 & $1 \cdot 1$ & 68 \\
\hline DEAE Sephacel & 40 & 100 & $2 \cdot 5$ & 57 \\
\hline Sephacryl S 300 & 22 & 84 & $3 \cdot 8$ & 48 \\
\hline
\end{tabular}

$\mathrm{mg}^{-1}$ and a recovery of $48 \%$ were obtained. The results of a typical purification procedure are summarized in Table 1.

\section{Partial characterization of CPO-F}

Purified CPO-F was not inhibited by azide and also showed other properties characteristic for bacterial nonhaem haloperoxidases. The $M_{\mathrm{r}}$ of the native enzyme was estimated to be 70000 . However, with a subunit size of $M_{\mathrm{r}}$ 29000 , as estimated by SDS-PAGE (not shown), it was not possible to decide whether the native enzyme comprises two or three identical subunits. Bromination of monochlorodimedone is strongly dependent on acetate with an optimal acetate concentration of $0.5 \mathrm{M}$. The enzyme is very stable against hydrogen peroxide. At a concentration of $150 \mathrm{mM}$ it still has about $50 \%$ of the activity shown at a concentration of $15 \mathrm{mM}$ which is the optimal hydrogen peroxide concentration for bromination of monochlorodimedone by CPO-F. The $\mathrm{pH}$ optimum for this reaction is at $\mathrm{pH} \mathrm{5.5}$. The chlorination of indole by CPO-F demonstrated that it is a CPO.

\section{DISCUSSION}

The fact that the non-haem CPO from $P$. pyrrocina catalyses in vitro the last two steps in pyrrolnitrin biosynthesis (Fig. 1), the chlorination of monodechloroaminopyrrolnitrin to aminopyrolnitrin (Wiesner et al., 1988) and the oxidation of the amino group of aminopyrolnitrin to the nitro group of pyrrolnitrin (Kirner \& van Pée, 1994), strongly suggested the participation of this enzyme in pyrrolnitrin biosynthesis. 
However, the lack of substrate- and regiospecificity of bacterial non-haem CPOs (Itoh et al., 1993; Bongs \& van Pée, 1994; Burd et al., 1995), the high $K_{\mathrm{m}}$ values for hydrogen peroxide $(1.6-30 \mathrm{mM})$ and bromide (11-69 mM) (Burd et al., 1995), as well as the presence of these enzymes in bacteria not known to produce halometabolites (Bantleon et al., 1994; Burd et al., 1995), casted some doubt on their role in the biosynthesis of halometabolites and nitrocompounds. To see whether bacterial non-haem haloperoxidases are really involved in the biosynthesis of halometabolites and nitrocompounds, we decided to replace the functional chromosomal $c p o F$ in a pyrrolnitrin-producing strain by a disrupted copy and measure the effect of this gene replacement on pyrrolnitrin production. However, it was not possible to use $P$. pyrrocinia for this experiment, as this strain is a poor producer of pyrrolnitrin and is resistant to many antibiotics used for selection in molecular genetics. Therefore, an oligonucleotide derived from part of the $\mathrm{N}$-terminal sequence of $P$. pyrrocinia CPO was used to clone a corresponding enzyme from the pyrrolnitrin producer $P$. fiuorescens BL914. The gene was originally cloned on a $9 \mathrm{~kb}$ EcoRI fragment. Subcloning resulted in a $3.8 \mathrm{~kb}$ EcoRI-BamHI (pSK380) and a 2.3 KpnI fragment (pSK230) containing $c p o F$. The $3.8 \mathrm{~kb}$ fragment was used for the construction of a replacement vector and the $2.3 \mathrm{~kb}$ fragment for isolation of CPO from recombinant $E$. coli clones. The isolation of CPO-F was based on the overexpression in E. coli and on the temperature and protease stability of bacterial non-haem haloperoxidases (van Pée, 1988; Zeiner et al., 1988). Determination of a few of its properties showed that the isolated enzyme belonged to the bacterial non-haem CPOs. The $M_{\mathrm{r}}$ of the subunits (29000) was very similar to that of other bacterial non-haem haloperoxidases (Pelletier et al., 1994; Bantleon et al., 1994; Burd et al., 1995).

Replacement of the chromosomal $c p o F$ gene in $P$. fuorescens BL914 by an inactivated copy via homologous recombination yielded mutants of $P$. fuorescens BL914 that, when transformed with the global regulatory gene for antifungal activity on the plasmid pCIB137 (Gaffney et al., 1994), produced pyrrolnitrin at the same level as the wild-type strain containing PCIB137. This clearly proved that CPO-F cannot be involved in either the chlorination of monodechloroaminopyrrolnitrin or in the oxidation of aminopyrrolnitrin.

The catalysis of unspecific halogenation (Bongs \& van Pée, 1994) and unspecific oxidation of amino to nitro groups (Itoh et al., 1993; Kirner \& van Pée, 1994; Burd et al., 1995) by bacterial non-haem haloperoxidases can be explained by the reaction mechanism of these enzymes, as suggested by Hecht et al. (1994). Bacterial non-haem haloperoxidases contain no cofactors or metal ions (Haag et al., 1991; Hecht et al., 1994); they only consist of amino acids. Comparison of the amino acid sequences and investigation of the three-dimensional structure of these enzymes revealed that they contain a catalytical triad, consisting of serine, histidine and aspartate residues (Hecht et al., 1994). The serine residue of this triad reacts with acetate forming a serine/acetate ester. This ester is not hydrolysed by water, but by hydrogen peroxide, resulting in the formation of peracetic acid (van Pée et al., 1994) which, as a strong oxidizing agent, can oxidize halide ions leading to the formation of hypohalide ions, powerful halogenating agents, or can oxidize aromatic amino groups to nitro groups. This mechanism explains the lack of substrate specificity, observed for bacterial non-haem haloperoxidases and why these enzymes could falsely be thought to be involved in the biosynthesis of metabolites like pyrrolnitrin.

Dairi et al. (1995) showed that in 7-chlorotetracycline biosynthesis, the halogenating enzyme is also not a bacterial non-haem haloperoxidase. Comparison of the gene for the chlorination step in 7-chlorotetracycline biosynthesis showed that there is no similarity between this gene and bacterial non-haem haloperoxidases and haem-containing haloperoxidases (Facey et al., 1996). The fact that non-haem haloperoxidases and haem-containing haloperoxidases (Facey et al., 1996) are not involved in the specific formation of halometabolites by bacteria, raises the question what kind of halogenating enzymes are actually involved in the biosynthesis of pyrrolnitrin and other halometabolites?

\section{ACKNOWLEDGEMENTS}

This work was supported by the Bundesministerium für Forschung und Technologie (BMFT) under contract 0319416A, the Deutsche Forschungsgemeinschaft (DFG) and the Fonds der Chemischen Industrie.

\section{REFERENCES}

Arima, K., Imanaka, H., Kousaka, M., Fukuda, A. \& Tamura, G. (1964). Pyrrolnitrin, a new antibiotic substance, produced by Pseudomonas. Agr Biol Chem 28, 575-576.

Bantleon, R., Altenbuchner, J. \& van Pée, K.-H. (1994). Chloroperoxidase from Streptomyces lividans: isolation and characterization of the enzyme and the corresponding gene. J Bacteriol 176, 2339-2347.

Bolivar, F., Rodriguez, R. L., Green, P. J., Betlach, M. C., Heyneker, H. L., Boyer, H. W., Crosa, J. H. \& Falkow, S. (1977). Construction and characterization of a new cloning vehicle. II. A multipurpose cloning system. Gene 2, 95-113.

Bongs, G. \& van Pée, K.-H. (1994). Enzymatic chlorination using bacterial nonheme haloperoxidases. Enzyme Micrab Technol 16, 53-60.

Burd, W., Yourkevich, O., Voskoboev, A. J. \& van Pée, K.-H. (1995). Purification and properties of a non-haem chloroperoxidase from Serratia marcescens. FEMS Microbiol Lett 129, 255-260.

Dairi, T., Nakano, T., Aisaka, K., Katsumata, R. \& Hasegawa, M. (1995). Cloning and nucleotide sequence of the gene responsible for chlorination of tetracycline. Biosci Biotech Biochem 59, 1099-1106.

Davis, R. W., Botstein, D. \& Roth, J. R. (1980). A Manual for Genetic Engineering. Advanced Bacterial Genetics. Cold Spring Harbor, NY: Cold Spring Harbor Laboratory.

Duggar, B. M. (1948). Aureomycin, a product of the continuing search for new antibiotics. Ann N Y Acad Sci 51, 171-181.

Ehrlich, J., Bartz, Q. R., Smith, R. M., Joslyn, D. A. \& Burkholder, P. R. (1947). Chloromycetin, a new antibiotic from soil Actinomycete. Science 106, 417. 
Elander, R. P., Mabe, J. A., Hamill, R. H. \& Gorman, M. (1968). Metabolism of tryptophan by Pseudomonas aureofaciens. VI. Production of pyrrolnitrin by selected Pseudomonas species. Appl Microbiol 16, 753-758.

Facey, S. J., Groß, F., Vining, L. C., Yang, K. \& van Pée, K.-H. (1996). Cloning, sequencing and disruption of a bromoperoxidasecatalase gene in Streptomyces venequelae: evidence that it is not required for chlorination in chloramphenicol biosynthesis. Microbiology 142, 657-665.

Gaffney, T. D., Lam, S. T., Ligon, J., Gates, K., Frazelle, A., Di Maio, J., Hill, S., Goodwin, S., Torkewitz, N., Allshouse, A. M., Kempf, H.-J. \& Becker, J. O. (1994). Global regulation of expression of antifungal factors by a Pseudomonas fluorescens biological control strain. Mol Plant-Microbe Interact 7, 455-463.

Gibson, T. J. (1984). Studies on the Epstein-Barr virus genome. $\mathrm{PhD}$ thesis, University of Cambridge, UK.

Haag, T., Lingens, F. \& van Pée, K.-H. (1991). A metal-ion- and cofactor-independent enzymatic redox reaction: halogenation by bacterial nonheme haloperoxidases. Angew Chem Int Ed Engl 30, 1487-1488.

Hager, L. P., Morris, D. R., Brown, F. S. \& Eberwein, H. (1966). Chloroperoxidase. II. Utilization of halogen anions. J Biol Chem 241, 1769-1777.

Hecht, H. J., Sobek, H., Haag, T., Pfeifer, O. \& van Pée, K.-H. (1994). The metal-ion-free oxidoreductase from Streptomyces aureofaciens has an $\alpha / \beta$ hydrolase fold. Nature Struct Biol 1, 532-537.

Hill, S. D., Stein, J. I., Torkewitz, N. R., Morse, A. M., Howell, C. R., Pachlatko, J. P., Becker, J. O. \& Ligon, J. M. (1994). Cloning of genes involved in the synthesis of pyrrolnitrin from Pseudomonas fuorescens and role of pyrrolnitrin synthesis in biological control of plant disease. Appl Environ Microbiol 60, 78-85.

Imanaka, H., Kousaka, M., Tamura, G. \& Arima, K. (1965). Studies on pyrrolnitrin, a new antibiotic. II. Taxonomic studies on pyrrolnitrin-producing strain. J Antibiot (Tokyo) Ser A 18, 205-206.

Itoh, N., Morinaga, N. \& Kouzai, T. (1993). Oxidation of aniline to nitrobenzene by nonheme bromoperoxidase. Biochem Mol Biol Int 29, 5194-5200.

Kirner, S. \& van Pée, K.-H. (1994). The biosynthesis of nitro compounds: the enzymatic oxidation to pyrrolnitrin of its aminosubstituted precursor. Angew Chem Int Ed Engl 33, 352.

Maurer, H. R. (1964). Disk-Elektrophorese: Theorie und Praxis der diskontinuierlichen Polyacrylamidgelelektrophorese. Berlin, New York: Walter de Gruyter Verlag.

McCormick, M. H., Stark, W. M., Pittenger, G. E., Pittenger, R. C. \& MacGuire, J. M. (1956). Vancomycin, a new antibiotic. I. Chemical and biological properties. Antibiot Annu 1955/56, 606-611.

Neidleman, S. L. \& Geigert, J. (1986). Biobalogenation: Principles, Basic Roles and Applications. Chichester: Ellis Horwood Ltd.

van Pée, K.-H. (1988). Molecular cloning and high-level expression of a bromoperoxidase gene from Streptomyces aureofaciens Tü24.J Bacteriol 170, 5890-5894.

van Pée, K.-H. (1990). Bacterial haloperoxidases and their role in secondary metabolism. Biotech Adv 8, 185-205. van Pée, K.-H., Salcher, O. \& Lingens, F. (1980). Formation of pyrrolnitrin and 3-(2-amino-3-chlorophenyl)pyrrole from 7-chlorotryptophan. Angew Chem Int Ed Engl 19, 828.

van Pée, K.-H., Hecht, H. J., Berkessel, A., Schrapel, T. \& Laatsch, H. (1994). Enzymatische, aktiven Sauerstoff liefernde Mischung sowie Verfabren zur enzymatischen Herstellung von Persäuren. German patent No P 44 327.0.

Pelletier, I., Pfeifer, O., Altenbuchner, J. \& van Pée, K.-H. (1994). Cloning of a second non-haem bromoperoxidase gene from Streptomyces aureofaciens ATCC 10762: sequence analysis, expression in Streptomyces lividans and enzyme purification. Microbiology 140 , 509-516.

Pfeifer, O., Pelletier, I., Altenbuchner, J. \& van Pée K.-H. (1992). Molecular cloning and sequencing of a non-haem bromoperoxidase gene from Streptomyces aureofaciens ATCC 10762. J Gen Microbiol 138, 1123-1131.

Sambrook, J., Fritsch, E. F. \& Maniatis, T. (1989). Molecular Cloning: a Laboratory Manual. Cold Spring Harbor, NY : Cold Spring Harbor Laboratory.

Schägger, H. \& von Jagow, G. (1987). Tricine-sodium dodecyl sulfate-polyacrylamide gel electrophoresis for the separation of proteins in the range from 1 to $100 \mathrm{kDa}$. Anal Biochem 166, 368-379.

Simon, R., Priefer, U. \& Puhler, A. (1983). A broad host range mobilization system for in vivo engineering: transposon mutagenesis in Gram-negative bacteria. Biotechnology 1, 784-790.

Southern, E. M. (1975). Detection of specific sequences among DNA fragments separated by gel electrophoresis. J Mol Biol 98, 503-517.

Stahl, E. \& Kaldewey, H. (1961). Spurenanalyse physiologisch aktiver, einfacher Indolderivate. Hoppe-Seyler's Z Physiol Chem 323, 182-191.

Vieira, J. \& Messing, J. (1982). The pUC plasmids, an M13mp7derived system for insertion mutagenesis and sequencing with synthetic universal primers. Gene 19, 259-268.

Vilter, H. (1984). Peroxidases from Phyophyceae : a vanadium (V)dependent peroxidase from Ascopbyllum nodosum. Phytochem 23, $1387-1390$

Wever, R., Plat, H. \& de Boer, E. (1985). Isolation procedure and some properties of the bromoperoxidase from the seaweed Ascophyllum nodosum. Biochim Biophys Acta 830, 181-186.

Wiesner, W., van Pée, K.-H. \& Lingens, F. (1988). Purification and characterization of a novel bacterial non-heme chloroperoxidase from Pseudomonas pyrrocinia. J Biol Chem 263, 13725-13732.

Whitaker, J. R. \& Granum, P. E. (1980). An absolute method for protein determination based on difference in absorbance at 235 and $280 \mathrm{~nm}$. Anal Biochem 109, 156-159.

Wolfframm, C., van Pée, K.-H. \& Lingens, F. (1988). Cloning and high-level expression of a chloroperoxidase gene from Pseudomonas pyrrocinia in Escherichia coli. FEBS Lett 238, 325-328.

Zeiner, R., van Pée, K.-H. \& Lingens, F. (1988). Purification and partial characterization of multiple bromoperoxidases from Streptomyces griseus. J Gen Microbiol 134, 3141-3149.

Received 29 January 1996; revised 11 April 1996; accepted 15 April 1996. 